\title{
Kritik Terbuka Sebuah Imperatif Budaya
}

\author{
Faruk
}

\section{Makna Kritik}

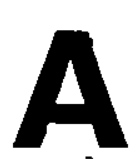

da satu tanggapan menarik terhadap peristiwa menyebarnya awan panas dari Merapi dua tahun yang. lalu di Yogyakarta, yaitu anggapan bahwa peristiwa tersebut merupakan peringatan dari Tuhan atas segala sikap dan perilaku manusia yang sudah menyimpang dari tata nilai dan norma yang baik sebagaimana yang digariskan oleh agama. Apabila anggapan ini benar, dapatkah dikatakan bahwa aktivitas Merapi menyebarkan awan panas yang menelan cukup banyak korban itu disebut sebagai sebuah aktivitas kritik?

Dua kemungkinan jawaban terhadap hal itu segera muncul, yakni ya dan tidak. Jika dipahami sebagai sebuah usaha untuk mengembalikan aktivitas warga masyarakat yang dianggap menyimpang dari tata nilai dan norma yang dominan, yang dianggap telah disepakati bersama, misalnya bahwa segala ajaran Tuhan merupakan satu-satunya pedoman bagi kehidupan manusia Indonesia, peristiwa itu akan cenderung dianggap bukan sebagai kritik, melainkan

- kontrol sosial. Akan tetapi, jika ajaran Tuhan dipahami sebagai seperangkat tata nilai dan tata moral yang marginal di hadapan misalnya tata nilai dan norma pembangunan kapitalistis yang sekular dan dominan, peristiwa itu akan cenderung dianggap sebagai produk aktivitas kritik. Dengan demikian, apabila kontrol sosial cenderung dipahami sebagai aktivitas pengendalian, kritik sosial cenderung dianggap sebagai âktivitas pembebasan dari segala bentuk kontrol dan pengendalian.

Di dalam kepustakaan filsafat dan ilmu sosial, seperti yang dikemukakan Sindhunata, pengertian kritik sebagai aktivitas pembebasan memang cukup melembaga. Dalam pengertian Kantian, kritis berarti kemampuan subjek untuk melepaskan diri dan mengambil jarak dari objek. Dalam pengertian Hegel kritis berarti kemampuan subjek untuk membangun sintesis dengan dan menyatakan dirinya dalam objek. Dalam pengertian Marx, hal itu dipahami sebagai kemampuan manusia merealisasikan dirinya dalam objek dengan mengubah objek itu. Dalam pengertian teori kritis mazhab Frankfurt kritis berarti kemampuan penyadaran diri manusia dari kekuatan hegemonik tertentu sehingga pada gilirannya manusia itu mampu melakukan periawanan dan pengubahan atasnya.

Tapi, benarkah ada yang dinamakan subjek =itu, subjek yang dibebaskan dan bebas tersebut? Postrukturalis dan atau postmodernis tidak begitu percaya akan kemungkinan yang demikian. Yang dinamakan subjek cenderung dipahami sebagai produk dari wacana. Bila demikian halnya, apa yang disebut sebagai kritik bukanlah suatu aktivitas pembebasan subjek, entah 
dari objek, entah dari objek, entah dari sistem hegemonik yang ada di luar dirinya, melainkan merupakan produk dari perbenturan antara dua atau lebih wacana yang berbeda. Dalam pengertian Berger, kemungkinan yang demikian dapat disebut sebagai perbenturan antara dua atau lebih definisi yang berbeda mengenai realitas.

Berger membedakan realitas sosial dengan realitas marginal. Realitas sosial adalah realitas kehidupan sehari-hari yang merupakan hasil konstruksi kolektif yang setelah mengalami proses tertentu berubah menjadi sesuatu yang seakan eksternal, objektif. Sebaliknya, realitas marginal merupakan realitas yang berada di luar kehidupan sehari-hari itu, baik yang berupa dunia mimpi-mimpi subjektif manusia maupun berupa realitas metafisik yang berkaitan dengan kehadiran maut sebagai sesuatu yang tak terelakkan bagi manusia. Realitas marginal ini selalu membayangi realitas sehari-hari di atas.

Sebagai sebuah hasil konstruksi, bukan sesuatu yang alamiah, realitas sosial keseharian tersebut merupakan sesuatu yang rentan, mudah atau setidaknya berada dalam ancaman yang terus-menerus untuk menjadi hancur atau punah. Karena itu, untuk menimbulkan kesan kealamiahannya, eksistensinya sebagai sesuatu yang hadir dengan sendirinya, yang berada di luar campur-tangan manusia yang mengkonstruksinya, realitas itu membutuhkan kekuatan legitimasi dari realitas yang ada di luar dirinya, realitas marginal yang dianggap bersifat transenden atau supernatural.

Karena itu, setiap definisi mengenai relaitas tak akan pernah dapat berdiri sendiri. la membutuhkan definsi lain demi kekokohan dirinya sendiri. Sebagai kekuatan legitimasi, realitas marginal itu cenderung berada dalam hubungan yang selaras dengan realitas keseharian. Namun, keselarasan tersebut tidak dengan sendirinya berarti lenyapnya perbedaan antara keduanya. Di mana dan kapan pun, tak akan pernah ada pengacauan antara realitas marginal dengan realitas keseharian, dunia di sini tak akan pernah identik dengan dunia yang ada di sana. Bahkan, dunia yang ada.di sana, seringkali dianggap sebagai berkebalikan dengan dunia yang ada di sini, seperti yang terlihat dalam bangunan dunia dalam ritus-ritus, termasuk misalnya dunia "tanah suci" bagi orang Islam. Apabila dunia sana dipahami sebagai dunia ideal yang surgawi, dunia sini hanya dapat berusaha mendekatinya meskipun tak akan pernah sepenuhnya serupa dengannya. Mungkin memang ada individuindividu tertentu yang mengidentifikasi kedua dunia tersebut, misalnya para sufi penganut gagasan jumbuhing kawula-gusti. Akan tetapi, dihadapkan dengan realitas keseharian, paham serupa itu menjadi bagian dunia yang marginal pula, bagian dari dunia mimpi subjektif.

Kuatnya kelembagaan kontrol sosial dalam masyarakat di mana dan kapan pun sekaligus menegaskan terbukanya kemungkinan lain dari apa yang ditetapkan oleh definisi dominan mengenai realitas. Dalam kasus masyarakat modern yang relatif terbuka, kemungkinan lain itu seringkali dikambinghitamkan sebagai pengaruh luar yang mengganggu. Akan tetapi, dalam masyarakat primitif yang tertutup, pengambinghitaman yang demikian tidak berlaku. Kemungkinan lain itu lahir dari tuntutan inheren dari masyarakat yang bersangkutan itu sendiri.

Karenanya, tak pernah ada azas tunggal dalam masyarakat mana pun. Memang selalu ada norma tertentu yang disepakati bersama, selalu ada hukum formal di dalam masyarakat. Akan tetapi, norma dan hukum itu tak akan dapat menerobos masuk dalam setiap detak jantung kehidupan war- 
ga masyarakat yang bersangkutan. Setidaknya selalu ada pertentangan atau setidaknya kesenjangan antara apa yang tertulis dengan yang tidak tertulis, apa yang ideal dengan yang nyata, apa yang sakral dengan yang profan. Sebagaimana yang dikatakan oleh Giddens, karena tak adanya bantuan peralatan teknologi yang canggih dan aparat kekuasaan yang terorganisasi secara luas, dalam negara tradisional-feodal, kecenderungan keterbukaan justru lebih besar daripada yang ada dalam negara modern. Dalam negara feodal, masyarakatmasyarakat pedesaan yang tersebar di berbagai tempat, cenderung mempunyai otonomi dalam pengaturan kehidupan keseharian mereka, termasuk bahkan dalam kehidupan politik seperti adanya sistem pemilihan lurah di Indonesia yang hanya barubaru ini mulai kehilangan otonominya.

Dengan kata lain, yang ingin saya katakan adalah bahwa kontrol sosial dan kritik sosial merupakan dua sisi dari mata uang yang sama, yang selalu ada di dalam masyarakat mana pun. Inherennya kontrol dan kritik sosial itu dimungkinkan oleh adanya sekurangnya dua definisi yang berbeda mengenai realitas meskipun di antaranya adanya yang dominan dan sentral dan ada yang subordinat dan marginal. Adanya dua atau lebih kemungkinan definisi tersebut merupakan produk dari kebutuhan sendiri yang ingin membangun sebuah dunia yang tidảk hanya tergantung pada subjektivitas dan temporalitas belaka, melainkan tergantung pada kekuatan yang ada di luar subjektivitas dan temporalitas.

Pemusnahan terhadap kritik sosial berarti pemusnahan kemungkinan definisi lain mengenai realitas selain yang dominan dan sentral, pemusnahan realitas marginal, dunia mimpi, dunia luar, yang sekaligus berarti pemusnahan kapasitas manusia untuk membayangkan adanya tatanan lain di luar tatanan yang ada. Hal itu akan se- kaligus berarti sebagai pemusnahan kapasitas manusia membangun sebuah dunia lain, membayangkan sebuah dunia yang tidak ada misalnya dunia supernatural yang justru menjadi kekuatan legitimasi terhadap yang ada. Karenanya, bangunan sosial yang ngotot dengan azas tunggal akan cenderung rentan. Dalam pengertian inilah dapat dikatakan bahwa aktivitas kritik merupakan sebuah imperatif kultural. la merupakan bagian integral dari usaha manusia untuk membangun sebuah dunia yang kokoh yang mampu memberikan rasa aman pada manusia yang bersangkutan sambil sekaligus membuka kemungkinan bagi pengembangan dunia itu ke arah yang semakin sesuai dengan tuntutan kemanusiaannya.

\section{Kritik dan Bahasa}

Dalam Kamus Besar Bahasa Indonesia Edisi Kedua, kritik diartikan sebagai "kecaman atau tanggapan, kadang-kadang disertai uraian dan pertimbangan baik buruk terhadap suatu hasil karya, pendapat, dan sebagainya'. Dalam Kamus Umum Bahasa Indonesia susunan W.J.S. Poenwadarminta, kata tersebut disebut mempunyai dua kemungkinan arti, yaitu (1) 'genting, kemelut, sangat berbahaya (tt. keadaan)' dan (2) 'celaan, kecaman, sanggahan'. Kamus yang pertama mengartikan kata mengeritik sebagai 'mengemukakan kritik, mengecam', sedangkan kamus yang kedua mengartikannya sebagai 'memberi pertimbangan (dengan mengemukakan manamana yang salah), mencela, mengecam'. Kamus yang terdahulu tidak memberikan contoh kalimat dari pengertian di atas, sedangkan kamus yang kemudian memberikan masing-masing satu contoh untuk kata kritik dan mengeritik. Contoh untuk kata pertama adalah "segala kritik yang 
pedas-pedas tidak diindahkannya", sedangkan untuk kata kedua "surat kabar itu selalu mengeritik tindakan Pemerintah".

Setidaknya ada dua masalah yang menarik dari pengertian dan contoh yang diberikan oleh kamus di atas. Pertama, kesinonimannya dengan kecaman dan celaan. Kamus pertama mengartikan ke-. caman sebagai 'kritikan, celaan, teguran yang keras'; sedangkan celaan cenderung diartikannya sebagai 'hinaan' 'menunjukkan cacatnya sesuatu' sehingga kata itu dipertentangkan dengan pujian. Kamus kedua mengemukakan pengertian kecaman yang sama dengan pengertian pada kamus pertama. Begitu juga pengertian celaan yang ada di dalamnya.

Dari beberapa pengertian tersebut tampak bahwa kata kritik, dalam bahasa Indonesia, cenderung mengandung konotasi yang negatif, dapat bersinonim dengan pengertian yang sepenuhnya berkonotasi negatif seperti celaan, tetapi tidak dapat bersinonim dengan kata yang berpengertian sepenuhnya positif. Kata kecaman mengandung kemungkinan arti yang positif, yaitu 'penyelidikan yang cermat', tetapi kata itu mengandung pula kemungkinan arti negatif, yaitu sebagai 'celaan'.

Kemungkinan di atas terkait secara konsisten dengan soal kedua, yaitu contoh yang diberikan. Contoh pertama menunjukkan sikap orang Indonesia pemakai bahasa Indonesia terhadap kritik, yaitu sikap "tidak perduli", bukan sikap "menerima". Contoh kedua menunjukkan persepsi orang Indonesia mengenai adanya sikap apriori dari suatu kritik, yakni adanya kata "selalu". Kecenderungan pengertian yang demikian pula yang seringkali dikemukakan oleh para pengamat sastra Jawa ketika mereka mencoba menjelaskan penyebab tidak hidupnya kritik dalam sastra Jawa. Mereka cenderung menganggap penyebab hal itu adalah persepsi negatif orang Jawa terhadap kritik, adanya anggapan orang Jawa bahwa kritik berarti 'aktivitas menjelek-jelekkan; mencela'.

Tapi benarkah Indonesia tak mengenal budaya kritik? Tentu tidak, Bila kita mengacu kepada lingkungan elit kerajaan masyarakat Jawa, kritik itu memperlihatkan dirinya dengan cukup menonjol. Pada masa transisi antara budaya Hindu-Budha dengan budaya Islam di wilayah tersebut, misalnya, terjadi persilangan definisị mengenai realitas yang membuahkan karya-karya kritik sosial seperti yang tampak pada kitab Darma Gandul. Pada masa transisi antara budaya feodal-tradisional dengan budaya modern, kecenderungan serupa terjadi seperti yang tampak dalam karya-karya Ronggowarsito, khususnya ramalannya mengenai zaman edan. Budaya plesetan yang hidup di lingkungan lapisan bawah masyarakat Jawa pun pada dasarnya adalah sebuah aktivitas dan hasil aktivitas kritik sosial, ketika definisi formal, tertulis, idealis mengenai realitas dihadapkan dengan definisi informal, lisan, dan berdasarkan kehidupan keseharian mengenai hal yang sama seperti plesetan kata bupati menjadi 'buka paha tinggi-tinggi', sekwilda menjadi 'sekitar wilayah dada', dan sebagainya. Belum lagi apa yang disebut dengan tradisi pepe. Dengan filsafat "kayu bersilang maka api hidup", masyarakat Minangkabau bahkan menjadikan kritik sebagai sebuah kekuatan utama bagi bangunan masyarakatnya. Di dalam lingkungan yang kemudian ini ketegangan antara adat dengan agama, darat dengan rantau, memang terus hidup dan bahkan mungkin dihidupkan.

Kritik merupakan bagian esensial dari masyarakat meskipun teori-teori sosiologi cenderung mengabaikannya. Yang mungkin membedakan masyarakat yang satu dengan masyarakat yang lain hanyalah cara pernyataannya. Karena dominasi budaya Jawa yang amat kuat, masyarakat Indo- 
nesia cenderung menggunakan cara kritik yang tersirat, yang disampaikan secara tidak langsung, misalnya melaluj simbolsimbol dan sebagainya. Akan tetapi, pényerapan cara kritik Jawa serupa itu tidak dapat dilakukan begitu saja, secara partial, tanpa mempertimbangkan tatanan masyarakat asalnya secara keseluruhan.

Pertama, masyarakat tradisional Jawa adalah masyarakat dengan tradisi lisan yang dapat dikatakan penuh. Karena bahasa lisan adalah bahasa yang terikat pada waktu, segera lenyap begitu diucapkan, dan karenanya tak dapat digunakan untuk menyimpan dan mengakumulasiikan informasi dengan tingkat kuantitas dan kompleksitas yang tinggi, masyarakat tradisional Jawa terpaksa menyederhanakan segala permasalahan menjadi "hitam-putih" atau setidaknya menampung berbagai permasalahan dalam sejumlah kata, kalimat, dengan permainan kesejajaran dan distingsi bunyi bahasa yang rinci. Kepekaan pada distingsi bunyi yang sangat halus, kemampuan menangkap kesejajaran bunyi, merupakan salah satu indikator utama dari kejawaan. Sejak lahir sampai matinya orang Jawa terus-menerus dididik untuk mempunyai kepekaan yang tinggi terhadap hal yang terakhir itu.

Kedua, bahasa lisan merupakan bahasa yang terikat pada kehidupan, pada dunia pengalaman, tak dapat dilepaskan darinya. Berbeda dari bahasa tulis yang dapat diisolasi atau dilepaskan dari manusia yang memproduksinya, dapat dilepaskan dari interaksi yang nyata antarmanusia, bahasa lisan sepenuhnya terikat padanya. Karena itu, komunikasi dalam bahasa lisan tidak sepenuhnya tergantung pada kata-kata, melainkan tergantung pula pada konteks dan situasi tempat dan wäktu kata-kata itu dihasilkan. Dalam hal ini, setiap warga masyarakat tradisional Jawa tidak hanya dituntut untuk peka terhadap kesejajaran dan distingsi bunyi yang halus, melainkan juga harus peka terhadap apa yang tidak dikatakan, yang terungkap dari sorotan mata, posisi tubuh, goresan garis bibir, gerak tangan, dan konteks bendabenda sekitar. Diam, dalam konteks bahasa dan komunikasi lisan, dapat mengandung banyak makna.

Ketiga, dalam konteks budaya lisan yang demikian, tidaklah mengherankan apabila di dalam masyarakat Jawa, salah satu kriteria bagi seorang pemimpin, seorang yang dianggap terhormat, adalah kemampuan bahasanya, kepekaannya terhadap kesejajaran dan distingsi bunyi yang halus, kepekaannya untuk menangkap makna yang tidak dinyatakan. Apa yang disebut sebagai tanggap ing sasmita, ingerti sakdurunge winarah, merupakan perumusan yang amat representatif dari kecenderungan yang demikian.

Keempat, kebutuhan material merupakan kebutuhan langsung manusia. Sehubungan dengan budaya lisan di atas, kecenderungan untuk melatih kepekaan akan ketidaklangsungan itu, masyarakat tradisional Jawa juga cenderung menghindari ekspresi langsung dari tuntutan atau dorongan pemuasan kebutuhan material. Ungkapan sepi ing pamrih merupakan rumusan yang sangat representatif dari kecenderungan yang demikian. Kesan ketidaktergantungan pada kebutuhan material sekaligus menjadi tolok ukur dari kepekaan manusia pada ketidaklangsungan. Empat kemungkinan di atas tidak dengan sendirinya berarti bahwa orang Jawa sepenuhnya formalitstis, hanya suka bermain bunyi tanpa makna, cenderung mendiamkan saja segala persoalan, atau tak mempunyai pamrih dalam kehidupan. Ungkapan ngono ya ngono, ning ojo ngono menunjukkan bahwa makna di balik bunyi itu ada, usaha untuk menyelesaikan persoalan pun terdapat, demikian pula segala macam 
pamrih akan pemenuhan kebutuhan material. Yang menjadi soal hanya cara penyampaiannya yang tidak langsung sehingga orang yang ingin memahami makna, memahami persoalan yang ada, dan pamrih dari orang lain, harus mempunyai kepekaan tertentu, semacam habitus dalam pengertian Bourdieu, yang diperoleh melalui pendidikan sejak bayi dan pengasahan yang terus-menerus sepanjang hidup.

\section{Penyebaran Budaya Kritik}

Indonesia terbangun ketika budaya tulis sudah menyebar luas, ketika segala tata kehidupan dirumuskan secara tertulis, ketika kompleksitas informasi ditampung dalam tulisan, baik dalam bentuk buku, majalah, maupun surat kabar, ketika industri percetakan telah mampu memperbanyak segala macam tulisan dan menyebarkan ke berbagai lingkungan masyarakat, ketika melek huruf tersebar semakin luas melalui pendidikan modern, dan yang tak kalah pentingnya, ketika bahasa Indonesia sudah ditetapkan sebagai bahasa nasioal, ketika segala bentuk tulisan sebagian besar menyampaikan berbagai informasi melalui bahasa Indonesia, serta ketika bahasa Indonesia dijadikan sebagai media resmi pendidikan nasional dan bahkan alat komunikasi dalam birokrasi.

Begitu dominannya tulis ini, segala ekspresi lisan yang semula sangat terikat pada kehidupan, tiba-tiba diisolasi menjadi tulisan. Dari pepatah-petitih, pantun berbagai dongeng, mitologi legenda, cerita wayang, mulai ditulis dan disebarkan melalui hasil-hasil cetakan yang bersifat massal, yang melampaui tidak hanya kehidupan warga masyarakat, melainkan melintasi komunitas asalnya secara keseluruhan. Begitu dominannya bahasa Indonesia, berbagai bentuk ekspresi itu pun mulai diterjemahkan ke dalamnya, bahasa
Jawa mulai tergeser, sehingga timbul banyak kecemasan di kalangan di kalangan tertentu mengenai semakin lemahnya kemampuan berbahasa Jawa orang Jawa sendiri.

Dalam situasi dan kondisi yang demikian, terjadi kecenderungan yang berkebalikan dengan kecenderungan pada budaya lisan di atas. Pertama, karena bahasa Jawa mulai tersisih, kepekaan warganya akan permainan kesejajaran dan distingsi bunyi pun menurun. Kedua, ketika berbagai informasi mulai dapat diperoleh melalui tulisan yang terisolasi dari kehidupan; kemampuan atau kepekaan warga akan apa yang tidak terucapkan pun menumpul. Kriteria seorang pemimpin nasional tidak lagi ditempatkan terutama pada kepekaannya, pada kemampuannya untuk tanggap ing sasmita atau ngerti sakdurunge winarah, melainkan pada kekayaannya, pada pendidikan modern atau kemampuan baca-tulisnya, pada kekuatan fisik-militernya, dan sebagainya.

Dengan demikian, masih relevankah, dalam situasi dan kondisi yang demikian, orang berbicara mengenai kritik sosial yang tidak langsung, yang berpola ngono ya ngono ning ojo ngono, yang menganggap diam berarti seribu kata-kata? Masih relevankah hal itu ketika yang tersisa sekarang pada banyak orang Jawa, terutama para pemimpinnya, hanyalah kuping yang budegbisu, yang tak mampu lagi mendengar suara-suara yang halus, lembut, samarsamar, yang tidak mampu lagi menangkap apa yang ada di balik kata-kata, di balik gerak, suara dalam kediaman? Masih relevankah penyembunyian pamrih dalam situasi yang demikian, situasi ketika sikap dan perilaku tanpa pamrih tak lagi menjadi ukuran kekuasaan, ketika sikap dan perilaku seperti itu bahkan dianggap sebagai kebodohan yang dapat dieksploitasi oleh hasrat pamrih yang merajalela? Masih 
relevankah itu ketika orang tak lagi punya malu dengan pamrihnya, menjadi robot-robot bermuka tebal bagai tembok?

Sebagai seorang yang telah cukup lama tinggal di Jawa, saya seringkali berusaha untuk menjadi Jawa, mencoba memecahkan permasalahan, melakukan kritik dengan cara Jawa. Pada suatu saat, misalnya, saya merasa sangat kecewa dengan sikap sembarangan rekan kerja saya dalam membimbing tesis mahasiswa. Dalam ujian saya menemukan banyak kesalahan pada karya tesis mahasiswa itu dan kesalahan itu menurut saya bukan terutama akibat kesalahan mahasiswanya, melainkan pembimbingnya. Namun, saya tidak menyatakan hal itu. Meskipun saya melakukan kritik yang keras terhadap karya itu, saya tetap memberikan nilai tertinggi padanya. Maksud saya, dengan cara itu, saya berharap mahasiswa dan dosen pembimbingnya menolak pemberian nilai yang bertentangan dengan kritik yang sudah saya lontarkan sebelumnya itu. Lalu, keduanya mencoba memperbaiki diri dan karya masing-masing. Tapi, seorang ahli budaya Jawa yang terkemuka, mengatakan pada saya bahwa cara itu cenderung sia-sia, karena baik si mahasiswa maupun si pembimbing sudah begitu budeg-bisu dan rai gedheg, tak punya malu, tak peka simbol.

Dalam Kolom "Ojo Ngono Ning Ngono" di Minggu Pagi, saya pernah bercerita tentang Mbah Karso, seorang petani miskin, yang telah membantu bekerja selama dua hari dua malam membantu seorang dosen yang menyiapkan acara sunatan anaknya. Seusai acara, si dosen tidak memberikan imbalan sedikit pun. Ini menunjukkan bahwa dosen itu, yang sebenarnya seorang dosen filsafat Jawa, tak lagi mempunyai kepekaan terhadap apa yang tak diucapkan oleh Mbah Karso. Kalau dia mengerti konsep sepi ing pamrih, konsep itu dipahaminya hanya secara wantah, seperti yang terdapat dalam teks-teks tertulis yang dipelajarinya, bukan sebagai konsep yang kontekstual, yang melibatkan diri dan latar belakang kemiskinan Mbah Karso.

Dengan demikian, melestarikan atau mempertahankan kritik terselubung dalam konteks budaya yang tidak lagi menopangnya, sama saja dengan membunuh eksistensi kritik sebagai sebuah institusi sosial yang lahir dari kebutuhan pengembangan hidup bersama manusia. Dalam konteks budaya tulis, budaya modern materialistis yang berpenopang pada budaya tulis di atas, pembangunan, pengembangan, dan penyebaran kritik terbuka, sama statusnya dengan pembangunan, pengembangan, dan penyebaran budaya kritik itu sendiri. Keduanya sama-sama merupakan imperatif bagi eksistensi manusia dalam dunia!

\section{Daftar Bacaan}

Berger, Peter L. and Thomas Luckman. 1967. The Social Construction of Reality. A Treatise in the Sociology of Knowledge, Garden City, New York: Doubleday \& Company, Inc.

Bourdieu, Pierre, 1993. The Field of Cultural Production. Colombia: Colombia University Press.

Ong, Walter J.'1986. Orality and Literacy: The Technologizing of the Word. London and New York: Methuen.

Sindhunata. 1982. Dilema Usaha Manusia Rasional: Kritik Masyarakat Modern oleh Max Horkheimer dalam Rangka Sekolah Frankfurt. Jakarta: Gramedia. 